Proc Soc Antiq Scot 144 (2014), 223-244

\title{
'The worst disaster suffered by the people of Scotland in recorded history': climate change, dearth and pathogens in the long 14th century
}

\author{
Richard Oram*
}

\begin{abstract}
Informing historical and archaeological discourse with environmental data culled from documentary and climate proxy records is transforming understanding of political, social economic and cultural change across the North Atlantic and European Atlantic regions generally. Limited record evidence and region-specific proxy data has hindered engagement by historians of medieval Scotland with the exploration of environmental factors as motors for long term and large scale change and adoption of the interdisciplinary methodologies involved in their use. This paper seeks to provide an overview of the potential for such data and methodologies in providing context for the well-rehearsed narratives of political upheaval and socio-economic realignment that have characterised much past Scottish historical discourse.
\end{abstract}

In mainstream English and Western European medieval historiography there is a long-standing tradition of research and writing on the impact of environmental factors on human society. Best represented in studies of the 14th century (eg Tuchman 1979; Pfister et al 1996), this tradition has its roots in 19th-century studies of the plague pandemic commonly known as the Great Mortality (eg Creighton 1894). Exploration of the immediate impact and long-term consequences of the pandemic has formed a central strand in much modern historical writing from the 1960s onwards, not least because of the wealth of graphic primary source material available from most regions of Europe but also because the nature and manner of our ancestors' responses to the plague hold up a mirror to contemporary experience from Spanish influenza, AIDS, SARS and avian influenza to ebola (see, for example, Ziegler 2003; Shrewsbury 1970; Ormrod \& Lindley (eds) 2003; Cantor 1997; Herlihy 1997; Naphy \& Spicer 2000 Cohn 2002; Jillings 2003; Benedictow 2004). English medieval social and economic history has also long recognised the influence of environmental factors on the agricultural regimes of the 13th and 14th centuries, although the primary focus was on issues such as population pressure and soil fertility rather than any wider interplay of anthropogenic and non-anthropogenic agency (eg Postan 1972: chapters 2-4). As a growing body of palaeoenvironmental and proxy climate data has become available from the 1990s onwards, that tradition has embraced the new evidence and been reconfigured by greater interdisciplinary interaction (see, for example, the 34 essays in Cavaciocchi (ed) 2010). By way of contrast, Scottish medieval historiography, with a handful of noteworthy exceptions, has failed to engage with environmental data, often citing poverty of documentary evidence as a reason for avoiding exploration of environmental issues. As a consequence, the study of Scotland's medieval history lags considerably behind research in England, Ireland and across most of North Atlantic Europe, where interdisciplinary analyses involving history, archaeology and various branches of the environmental sciences

* University of Stirling 
have revolutionised understanding of humanenvironment interactions and their influence on wider social evolution.

It is not the aim of this paper to provide an environmental history of medieval Scotland or even just of the 14th century in Scotland; that is a much larger task than can be addressed here. Rather, the intention is to explore the nature of the evidence that is available within the documentary record and place it alongside the various forms of proxy data for climate history to produce a synthetic narrative. There will remain gaps, particularly where the domestic Scottish record is significantly deficient in the first half of the 14th century, but these can be filled in part by reference to the sources available in adjoining areas (especially northern England and Ireland). It must be emphasised that this paper will remain an examination of what happened not why it happened as it did. Environmental scientists can posit why and how certain climate phenomena occurred; we cannot, however, determine exactly why human populations chose to respond to those phenomena in the way that they did.

Laments for the passing of 'the Good Old Days' are common in any era, but it was long accepted that the rhymes bewailing the death of King Alexander III and the end of his reign's 'golden age' reflected a popular view that there had been a genuine break from an era of peace and prosperity into one of protracted political crisis and near disaster. The deteriorating weather, wars, famine and pestilences of the 14th century provide context for the second part of that view, but there are mounting questions about the reality of the later 13 th-century 'golden age' that supposedly died with the king. Although now viewed as an allegorical reference to the political crises and wars which flowed from the failure of the senior male line of Scotland's royal house at the close of the 13th century, it can be said that the recurrent blows of extreme weather, famine, epizootic and epidemic disease in 14thand early 15 th-century Scotland might as easily have provided inspiration for the lines of Andrew of Wyntoun's Orygynale Cronykil of Scotland (1424):
Quhen Alexander our kynge was dede, That Scotland lede in lauche and le, Away was sons of alle and brede, Off wyne and wax, of gamyn and gle (Laing (ed) 1872: II, 266).

Wyntoun may have adopted the stanza from verses composed originally in the uncertain years immediately following Alexander's death in March 1286. By Wyntoun's day, however, the lament for a lost 'golden age' had gained even greater force through a succession of environmental shocks - climate change, dearth and pathogens - which had thrown over traditional livelihoods and social systems and ravaged the human and animal populations of Scotland.

How prosperous was late 13th-century Scotland? Traditional reading of the historical record is that after the political factionalism of Alexander's minority (1249-59), the kingdom enjoyed a generation of peace, stability and economic prosperity (Brown 2004: 56). Indeed, assessments of the wealth of Scotland in terms of the volume of silver coinage in circulation or capital-intensive building programmes reflected in work at cathedrals and monasteries around the kingdom or invested by secular lords in castlebuilding projects, point prima facie to an era of continuous economic growth and confidence that had been triggered and then sustained by population growth and consumer demand (Mayhew 1990; Fawcett 2011: chapters 3 and 4). All of this, it has been suggested, was built on a benign climatic regime that prevailed down to c 1300. Warmer and milder conditions beginning in the 11th century, coupled with innovations in agricultural technology, had increased the carrying capacity of the land, delivered better yields and encouraged the expansion of agriculture to support a growing population (Dyer 2002: chapters 3-5; Duncan 1975: 310-11); veritably an age of abundance of ale and bread. Aspects of this idyllic picture have long been questioned, however, usually through comparisons with conditions in England since hard economic statistical evidence is almost wholly lacking for Scotland before the mid-14th century (Gemmill \& Mayhew 1995). In England, by contrast, an 
abundance of record evidence has permitted construction of labourers' wage and price series in key commodities from which inflationary pressures - and their causes - can be modelled (eg Thorold Rogers 1866-1902; Phelps Brown \& Hopkins 1981; Campbell 2007; Clark 2008; Munro 2008). Such series have enabled it to be shown that English population growth slowed in the later 13th century while environmental stress had increased (Campbell 2009; Campbell 2010). For Scotland, the traditional positive vision can also be challenged, despite the absence of the hard numerical evidence (Oram 2011: chapter 7). Far from gorging themselves on Nature's gifts in the later 13th century, it is more likely that much of Scotland's population lived on the proverbial knife-edge of subsistence.

What is the evidence for less-than-favourable environmental conditions in the later 1200s? A shift in the northern hemisphere's general climate system is reflected in European chronicle sources from 1256 onwards, the events of that year signalling the beginning of a trend that accelerated towards the end of the decade. For Scotland, the Lanercost chronicler's account stands as an indication of the local impact:

In this year there was so great corruption of the air, and inundation of rain, throughout the whole of England and Scotland, that both crops and hay were nearly all lost. And some men's corn rotted in the fields from the day of harvest; some men's corn, shaken out by the wind, grew again under the straw; some men's harvest was so late that they did not reap it until about the festival of St Martin [11 Nov] or later...

(Stevenson (ed) 1839: 64)

Consequently, 1257 saw 'the greatest dearth of grain' throughout the whole of the British Isles with shortages of flour for bread and malt for brewing and severe social dislocation arising from the tensions produced by the famine conditions (Stevenson (ed) 1839: 651; Luard (ed) 1880: 607, 630; Campbell 2009). For 1260, a 13th-century account incorporated into Walter Bower's Scotichronicon records food shortages and price inflation stemming from harvest failures; violent storms throughout a dry summer; a wet harvest season (threatening further food shortages to come); and destructive gales through the late autumn and early winter (Watt et al (ed) 1990: 325). The result in 1261-2 was that 'all parts of Scotland suffered from a great famine caused by the harvest being ruined' (Watt et al (ed) 1990: 335). Similar weather continued through 1263 , including the gales that battered the Norwegian fleet off Largs (Watt et al (ed) 1990: 341). More came in 1267, when a mild, dry summer raised hopes of an abundant harvest but dashed them, first by plant-eating insect infestations and then by violent easterlies in late October that pounded the coast between the Tweed and the Tay and caused tidal surges up the river estuaries to flood low-lying agricultural land (Watt et al (ed) 1990: 359, 361). Winter 1267-8 brought severe conditions that continued into a cold, wet and windy spring and summer for 1268 , in which it was reported 'there was a high deathrate amongst animals, that is amongst red deer, fallow deer, forest ponies, but most of all sheep', and that ended with a winter so harsh that the ground could not be ploughed between the end of November 1268 and the beginning of February 1269 to prepare for sowing (Watt et al (ed) 1990: 369, 373). In north-eastern Ireland, the Annals of Ulster recorded 'great, unbearable famine' (Annals of Ulster: 1268.3). The new decade brought continuing misery, with general famine in 1270 affecting Britain and Ireland (Annals of Loch Cé: 1270.6; Annals of Connacht: 1270.14) and, in 1272, 'a great lack of productivity of the land and unfruitfulness of the sea, as well as turbulence of the air, as a result of which many people fell ill and many animals died' (Watt et al (ed) 1990: 381, 385, 387). It was not just Scotland that experienced these disasters, for Bower's source reported that 'great famine hit France, England, Scotland and many areas, for the cattle mostly died, the crops died and the poor died of their poverty' (Watt et al (ed) 1990: 385, 387). English records suggest a continuation of such conditions into the 1280 s, with harsh winters and late springs producing delayed harvests and the resulting risks of reduced yields in wet and windy autumns (Stevenson (ed) 1839: 122). Hardly the picture 'Off wyne and wax, of gamyn and gle' 
throughout the reign of Alexander III that has passed into popular tradition.

Interpretation of the wider climatic situation from such generic chronicle evidence alone is problematical and, unlike England, there is an absence of population, price and wage data - even after the beginning of the regular Exchequer Roll sequence in the late $1350 \mathrm{~s}$ - that can be used to offer corroboration and model long-term impacts of such events. Alongside data embedded in the narrative sources, however, proxy environmental measures can offer a long-term perspective that may give context for events reported in the historical record, an approach exemplified for the English experience in the work of Professor Bruce Campbell (Campbell 2009; see also Baillie 1999). It is, of course, research into current global climate change that has driven forward the interrogation of palaeoclimate records; these advances have used a variety of different proxies, including ice-core, ocean sediment and tree-ring data (eg Baillie \& Brown 2005; Briffa 2000; Briffa et al 1998; Briffa et al 1999; Dawson et al 2007; Oppenheimer 2003; Strothers 2000). Many of these data are region-specific but a synthesis of different sources can be used to examine climatic changes both over wider spatial areas and longer temporal periods. For the period $c 1150-c 1650$ there are climatic proxies with annual or seasonal resolution located over a wide geographic range across the northern hemisphere. The proxies employed as summer and winter temperature indicators - Ural and Siberian tree-ring data (Briffa et al 2001) and the Greenland Ice Cap respectively (eg Adderley \& Simpson 2006; Dawson et al 2007; Vinther et al 2003) - are, obviously, distant to Scotland and should not be used as absolute indicators of climatic variability here, due to the ameliorating or worsening effects of other oceanic and atmospheric factors the further removed a locale is from the context in which the data was obtained. The approach most commonly pursued, therefore, is to contrast Northern Hemisphere/North Atlantic summer temperatures from dendrochronological analyses: stable isotope records providing an index of relative winter 'severity' from ice core data and for an annualised long-multi-proxy mean (Crowley \& Lowery 2000; Oram \& Adderley
2008). Such annualised multi-proxy data indicates that there was a long period of higher annual mean temperatures that began before $\mathrm{AD}$ 1000 and continued into the later 13th century what is referred to as the 'medieval warm period' or 'medieval climate anomaly' [hereafter MCA] - but within this timeframe, both proxy data and historical accounts are punctuated regularly both by cold episodes and by extreme weather events.

A synthesis of the data permits the general trend in weather events that were driven by these climatic shifts to be seen quite clearly. A sharp episode of cooling in the 9th and 10th centuries opens the period. It is recorded in human experience in chronicle accounts and Norse sagas - and in the ice core data in the evidence for an immense volcanic eruption in southern Iceland that produced some 220 million tonnes of sulphate aerosols which, combined with atmospheric water vapour, created around 450 million tonnes of dilute sulphuric acid that circulated the planet in the troposphere. More recent measured episodes permit us to infer what the impact of such an event might have been on the global climate; the planet-wide cooling which resulted from the 1991 eruption of Mt Pinatubo in the Philippines, less than one-tenth of the scale of the 10th-century Icelandic eruption (Self et al 1998), suggests that there may have been decades of instability, marked by colder winters and, probably, by wet summers memorable for acidic rainfall that stunted growing crops. As this episode faded, temperatures again climbed to produce an era of milder conditions that spanned the 11th and 12th centuries.

Saga descriptions of extensive sea ice east of Greenland in the 1200s provide context for historically attested episodes of low winter temperatures and increased storminess in these islands, especially between $1233-4$ and 1248, a period characterised by cold, icy winters peppered with violent storms in Britain and Ireland. Then the 1250s brought recurring drought conditions 'the greatest heat and dryness' in 1252 (Stevenson (ed) 1839: 57) - alternating with saturation for much of the British Isles, as already noticed for 1256 (Stevenson (ed) 1839: 64). A trend towards more unstable conditions was evidently already established but profound and lasting change 
occurred in 1258. High concentration of volcanic sulphates found in ice cores from Greenland and Antarctica indicate that another major volcanic eruption, now identified as a 1257/8 eruption of Gunung Rinjani, on the island of Lombok in Indonesia, expelled vast amounts of material into the atmosphere, sufficient to entrench the downward spiral of climatic cooling (Briffa et al 1998; Dawson et al 2007; Oppenheimer 2003; Strothers 2000). A rapid southward extension of sea ice off Greenland again heralded poor summers and severe winters for Britain through the 1260s, 1270s and 1280s, illustrated by Bower's account of food-shortages and storms in summer 1260 , followed by a wet autumn and stormy winter (Watt et al (ed) 1990: 325).

What climate processes were behind these events? A combination of atmospheric and oceanic circulation systems drive climatic shifts like those experienced by Scotland between $c 1250$ and $c 1400$ (see eg Mayewski et al 1994; Dawson et al 2007). Changes in ocean surface temperatures affected the pattern of east-flowing Atlantic weather systems reaching the British Isles. In particular, ocean-surface warming increased atmospheric moisture and triggered increases in storminess, with some extreme summer wind and rain events, and periods of extreme heat or coldness often seen in records of hot, wet summers and prolonged snow and ice in late winter (Dawson et al 2007: 431). Conversely, extension of the southward range of sea ice increases the incidence of winter storms as the cold surface temperatures leads to the high surface air pressures associated with anticyclonic circulation. This draws cold air further south to collide with warmer moist air moving east across the Atlantic. The result is stormy winters and cold, late springs, adverse summer growing conditions and wet and delayed harvests. That trend was already evident across Alexander III's so-called 'golden age', but from around 1300, the shift towards colder annual temperatures in the northern hemisphere became entrenched, signifying the 'end' of the MCA. Anticyclonic circulation established a seasonal pattern of harsh and bitterly cold winters; delayed and relatively cool springs; hot and dry summers and warm, wet autumns from around 1308 (Pfister et al 1996).
Then, in $1314 / 15$, a dramatic change occurred with the beginning of what has been labelled the 'Dantean Anomally' (Brown 2001: 251-4), with the summers turning cold and delivering almost continual frontal systems, with unprecedented rainfall across the British Isles that resulted in late, meagre harvests with shortages of grain for human consumption and fodder for livestock (Campbell 2009: 32-4, 42-3; Jordan 1996: 16-23; Kershaw 1973). Evidence from the Greenland ice cores indicates that this episode stemmed from a rapid rise in North Atlantic ocean-surface temperatures in the summer months, an overheating that continued through the winter to trigger an upward spiral in temperatures and a concomitant increase in atmospheric moisture. These conditions peaked around 1318-19 but it was not until 1325 that a further change was manifest in the form of a return to summer droughts. This episode was short-lived, however, with some indication of a return, by the early 1330s, to the wet conditions of the previous decade, but this yielded swiftly to a plunge to the lowest temperatures experienced across the North Atlantic region since before 1000. While this plunge in temperatures has been described as 'a period of polar cooling that is minor by glacial standards' (Mayewski et al 2004: 252), it was the catalyst for a series of dramatic changes in social organisation and economic structures in Scotland, Ireland, Iceland and Greenland (Dugmore et al 2007; Dugmore et al 2009; Lyons 1988; McGovern et al 1988; McGovern et al 2007; Oram 2010; Oram \& Adderley 2008; Oram \& Adderley 2010). The cumulative effect of these extended episodes over many years had been more pronounced than the traumas created by shorter periods of year-to-year variation.

While considerable debate remains over the exact chronological range to which the term should be applied, the climatic cooling evident through the 14th century, despite some recovery in temperatures between $c 1350$ and $c 1420$, can be seen as the first stage of the so-called 'little ice age' [LIA] that lasted until the middle of the 19th century (Whittington 1985; for general discussion, see Fagan 2000; Mann 2002). Again, as with the generic, 'medieval climate anomaly' label, the LIA was not a period of unmitigated climatic 
deterioration and relentless cold weather. The 1350s had seen unprecedented low temperatures, but it was a very cold episode that commenced soon after 1400 that helped to entrench the effects of the cooling. Winter storms in the North Atlantic became more regular, more violent and more prolonged, and the south-west to north-east circulation of warmer water that helped to give the British Isles their generally milder climate moved south as colder, polar circulation systems extended (Mayewski et al 1994). The direct result of this was that the North Atlantic winter storm track that passed over Iceland and the Faroe Islands became fixed instead over Britain; storm systems flowing in from the Atlantic collided with cold air drawn by anticyclonic circulation from Russia, resulting in snow. The sea ice retreated northward slightly in the middle of the 15 th century, but it would be wrong to call this a period of warmer mean temperatures; it was less cold than what had preceded it.

In contrast to the detailed records of the socio-economic impact on England and Ireland of the poor weather in the first quarter of the 14th century, little comparable evidence survives for Scotland. Dire accounts from Ireland and northern England, however, allow little doubt that Scotland's experience was similar (Jordan 1996: 97-103, 117-20, 171-7; McNamee 1997: 10515). The well-informed Lanercost chronicler was one of the few authorities to comment on crop failures and famine in southern Scotland, noting that in 1316 there was 'mortality of men through hunger and pestilence, unheard of in our times' (Stevenson (ed) 1839: 233). Towards the end of this phase, Bower recorded a severe winter in 1321-2, "which was a sore trial to men and killed off nearly all their animals' (Watt et al (ed) 1996: 11). Political upheavals and wars that resumed in the 1330s preoccupied the few active chroniclers in Scotland in the second quarter of the 14th century, but English and Irish sources reveal a return of weather conditions that had produced famine between 1315 and 1322 (Annals of Connacht: 1328.3, 1328.10, 1335.6, 1339.4; Annals of Loch Cé: 1328.2, 1328.9, 1335.5, 1339.8). The bitterly cold winter of 1349-50 passed without comment in Scottish sources but, probably because the event was especially damaging to English interests, tempests are recorded in February 1356, when an English fleet came to grief off North Berwick (Watt et al (ed) 1996: 289, 291). Such devastating winter storms continued through the following decades, one in December 1372 being described as bringing extensive property damage as well as flattening woodland (Watt et al (ed) 1996: 375). The summers, however, were equally bad and harvests suffered from late, heavy rains; a major event resulting in severe flooding affected much of Lothian in September 1358 (Watt et al (ed) 1996: 311, 313).

What impact might such climatic deterioration have had on political events from 1296 onwards? Two examples from the Wars of Independence can provide some illustration of potentially weather-influenced outcomes. Environmentrelated economic pressure probably played as significant a part in Scottish resistance to Edward I of England's treasurer in Scotland, Hugh Cressingham's efforts to raise tax in 12967 or to secure recruits to serve in France (Barrow 1988: 78, 85, 86; Prestwich 1988: 476-8). Records of continuing severe winters, poor summers and failed harvests throughout Britain into the mid1290s (Stevenson (ed) 1839: 141, 145, 154, 157, 158; Watt et al (ed) 1991: 41), coupled with indications of outbreaks of sheep scab in Scotland during the same period, suggest that it was not simply insurgency at work. Quite simply, there may have been little with which to pay and Wallace and Murray capitalised on economic distress to recruit soldiers. Environmental factors more obviously affected the outcome of military operations in the Bruce brothers' invasion of Ireland in 1315-18 (McNamee 1997: chapter 5). Hopes of an easy victory after initial successes were dashed as much by climatic deterioration as by the failure of the Gaelic Irish to join with the Scots against the English. The opening of the campaign coincided with the start of seven years of almost unbroken harsh winters, poor summers and failed harvests across northern Europe, in which as much as $10 \%$ of the population perished. Barely able to feed themselves, the Irish peasants responded violently to the Scots' attempts to collect the supplies promised by their allies. No similar data survives to illustrate the impact of these famine years on Scotland, but 
given the recorded experience around the western and northern coasts of Ireland and in northern England, it is unlikely that Scotland fared any better; King Robert had little to send to aid his brother other than still more mouths to feed.

The Great European Famine, as this sevenyear event is now known, is discussed most often in terms of catastrophically low arable yields, a view based on the better records that have survived from cereal-producing regions (Jordan 1996; Kershaw 1973). Late, cold springs and wet summer weather, however, did not just lead to falling arable yields, for all plant growth was affected. While grass will continue to grow in even comparatively poor summertime conditions, the degree of growth is affected by drought or wet, sunlight availability and temperature; the minimum growing temperature for grass is $6^{\circ} \mathrm{C}$. Long-stemmed grasses, as harvested for hay, are also as prone to flattening by severe weather conditions, accelerating the spoiling of the crop through fungal growth, rotting and insect infestation (Jordan 1996: 37). Grass growth is likely to have reacted adversely during the Dantean Anomaly and assessment of the impact of these crisis years is that hay crops failed, summer pastures in the uplands became less capable of sustaining the numbers of animals grazed there previously, and winter pastures became stressed as the flocks and herds had to be grazed there for longer into the spring and from earlier in the autumn. When the first episode of severe weather ended in 1322-3, however, there was no 'bounce-back'; the climate proxies show that conditions remained cooler and slightly wetter, and a trend towards a colder climate generally continued into the middle of the 14th century. The result of this was intense pressure on Scotland's pastoral economy and the vital cash crops - wool and hides - that it produced.

Terrible though the impact of war and famine was, recurring outbreaks of widespread disease from the 1250 s amongst animals (epizootics) and human populations (epidemics) introduced biological agency as a causal factor in major environmental, socio-economic and cultural change (Campbell 2008; Campbell 2009; Campbell 2010; Newfield 2009; Slavin 2010). Arguments that the onset of these animal and human plagues was linked to the major climatic events of the period are not widely accepted amongst academics, but traditional explanations for their nature and spread are equally questionable. Widespread murrains afflicted cattle in England in 1252 and then sheep in 1254, with reports of up to one half of the flocks perishing, and, in 1258, when the disease struck in the aftermath of a mild but wet winter (Luard (ed) 1880: 427, 674). Epizootics may have been responsible for unusual levels of mortality amongst wild animals and domesticates across Scotland, recorded as early as 1268 and 1272 (Watt et al (ed) 1990: 369, 373, 385, 387), but these incidents also coincided with unusually severe winters and associated dearths. Like the 1252 and 1258 episodes in England, the coincidence of the weather events of 1268 and a livestock disease outbreak affecting Lothian - referred to as lungessouth - is striking (Stevenson (ed) 1839: 85), but the 1328 outbreak in north-east Scotland has no such obvious correlation (Stuart \& Burnett (eds) 1878: 148). Both episodes, however, came at the end of protracted periods of comparatively poor conditions and may reflect the cumulative effects of environmental stress on pasture and livestock. Animal health was of critical concern for a society heavily dependent upon the income derived from livestock. The extent of that concern is revealed in royal mandates, issued in the early 1320 s, aimed at preventing the spread of sheep diseases referred to variously as scab, 'pilsoucht' or 'pluk' (Barrow 1988: 298-9; Duncan (ed) 1976: no 16).

While scab was a recurring problem and cattle murrains were recorded in Irish sources in the 1290s and early 1300s (Annals of Connacht: 1286.3, 1302.7; Annals of Innisfallen 1296.2; Annals of Loch Cé: 1308:10; Annals of Ulster: 1298.5 [recte 1301]), something new occurred in a devastating plague that affected oxen and cattle across western Europe between $c 1315$ and 1325 (Newfield 2009; Slavin 2010). Herds in south-eastern England were first affected in 1318-19 (Newfield 2009: 163-8), with the outbreak reaching the border by August 1319, perhaps in infected livestock brought to supply Edward II's army besieging Berwick, from where it spread west into Cumberland (Newfield 2009: 
169; Slavin 2010: 167; Stevenson (ed) 1839: 240) and probably north into Scotland (Newfield 2009: 175). Again, the loss of Scottish records from this period renders it impossible to calculate its impact on Scotland, but references to "the great cattle slaughter' in Ireland, where it reached in 1320/1 (Newfield 2009: 169-70; Annals of Connacht: 1321.5, 1324.4,1325.7; Annals of Loch Cé: 1321.4, 1324.3, 1325.6; Annals of Ulster: 1318.7 [recte 1321], 1321.2 [recte 1324], 1322.5 [recte 1325]), and English manorial accounts that indicate regional variation from zero to $85 \%$ but with an average of $50 \%$ of the meat and dairy herds and draught oxen perishing, give a stark image of the likely effect (Campbell 2010: 26-7 and Fig 7A; Slavin 2010: 169, 177-9). Poultry was the next species to be affected, it being noted in Gesta Annalia that in 1344, fowls throughout Scotland suffered a disease that so terribly spoiled their flesh that no-one might eat them (Skene (ed) 1872: 358)

Cattle, sheep and poultry epizootics paled into insignificance behind the human pandemic that affected Europe after 1347. Labelled by the Scots as 'the foul death of England' when it afflicted their southern enemy in 1348 (Horrox (ed) 1994: 78), the taunt ended in 1349 when the plague entered Scotland. In contrast to the agonised outpourings of contemporary English and European writers, there is only one surviving 14th-century Scottish account of the epidemic, that embedded in the Gesta Annalia, which states simply that 'there was in the kingdom of Scotland so great a pestilence and plague amongst men ... as ... had never been heard of by man', that 'fully a third of the human race was killed', and that its main victims were amongst 'the meaner sort and common people' rather than the magnates (Skene (ed) 1872: 359). It is reported in only slightly less restrained terms in the early 15 th-century accounts of Wyntoun and Bower, at the time of whose writing Scotland had suffered at least three further outbreaks (Laing (ed) 1879: III, 80-1; Watt et al (ed) 1987: 273). Detailed accounts of how widely Scotland and its adjacent islands were affected in this 'Great Mortality' are lacking. The mid-14thcentury chronicle used by Fordun is a unique source for the general Scottish experience, but provides no insight of regional variation or local experience of mortalities. Records of subsequent waves of epidemic concentrate on the Lowland and primarily East Coast experience, skewing our perspective of the plague's potential impacts and offering no clear view of how societies away from the zones of nucleated settlement were affected. One Icelandic source, the Lawman's Annal, records how 'pestilence visited the Shetland Islands, the Orkney Islands, the Hebrides and the Faroe Islands' (cf Benedictow 2004: 154), but it offers no comment on how it reached there, mortality levels in those areas or on how local society was affected by the loss of population. Again, we are required to extrapolate likely consequences from the better-recorded English and Irish experience.

A second epidemic occurred in 1362-3, which, according to Bower, killed one-third of those who had survived the first pestilence (Watt et al (ed) 1996: 319). This epidemic may have been more pronounced in the southern part of Scotland, King David II and his household moving north to escape infection (Webster (ed) 1984: 309, 317 and nos 276-85), but there is little other evidence to indicate its rate and extent of spread. One charter to the canons of Holyrood, issued on 2 February 1362/3, refers to injuries to them on account of war and pestilence, but this is couched in general terms and does not specifically identify actual losses on the abbey's property as a consequence of the epidemic (Innes (ed) 1840: no 98). It was followed by a third occurrence in 1380 that Bower again claimed killed one-third of the remaining people (Watt et al (ed) 1996: 381). He also adds that the epidemic was believed to have been brought to Scotland by soldiers returning from a plundering raid into the north of England. It has been suggested that there may have been an outbreak in 1392, possibly spreading north from the epidemic that had begun in England in 1389 and which ravaged York in 1391 (Shrewsbury 1970: 137-8), but there is no contemporary record of this event in Scottish sources. A fourth documented outbreak struck in 1401, but with apparently diminishing levels of mortality (Watt et al (ed), 1987: 39). With such limited reference to these incidents in 14th- and 15th-century narrative accounts, it is unsurprising that plague has almost disappeared from the reckoning in 
most modern academic histories of 14th- to 17th-century Scotland and its impact beyond the urban centres consistently downplayed. This is an historiographical phenomenon that has been discussed elsewhere (Oram 2008: 13-14, 16-18), but it bears restatement that there is no evidence to support views that plague was ever purely or even largely an urban problem in later medieval Scotland, or that rural populations were any less severely affected by plague epidemics.

Only Sandy Grant has offered the sober but unsubstantiated opinion that 'plague still appears to have been the worst disaster suffered by the people of Scotland in recorded history' (Grant 1984: 75). There are no exact figures for mortalities, but contemporary sources speak of 'fully a third of humanity', and more, perishing (see, for example, Horrox (ed 1994; Benedictow 2004: chapter 33). At that level, now widely regarded as an underestimate, when the first outbreak ended in 1351-2 at least 130,000 of Scotland's estimated population of around 500,000 were dead. Plague mortalities declined steadily in later outbreaks, possibly because different pathogens were at work but not distinguished by chroniclers who labelled all simply as 'plague' or 'pestilence', but new diseases also ravaged the survivors in the 15 th century. In 1402 , for example, there was a major outbreak of dysentery affecting eastern Scotland. Victims died 'in profluvio ventris' ('with outflowing of the bowels' ie diarrhoea) (Watt et al (ed) 1987: 45), with Exchequer business disrupted on account of the outbreak and several deaths reported as far north as Dundee, where the burgh's bailies were reported to have died from it (Burnett (ed) 1880: 553, 579; Shrewsbury 1970: 149). Bower's description of the illness in 1420 that caused many deaths and which the common people named 'le qwhew' has led to its being identified as influenza (Watt et al (ed) 1987: 117). Influenza is also offered as the 'swiftly-spreading pestilence' that broke out in Edinburgh in February 1431 and in Haddington in 1432 (Watt et al (ed) 1987: 265, 277; Creighton 1894: 234; Shrewsbury 1970: 150). The high mortalities of the famine of 1439 were accompanied by an epidemic labelled 'the wame ill' (stomach or intestinal disorder) in the so-called Auchinleck Chronicle that, according to the chronicler's account, killed as many people as in any previous pestilence, with a second wave of the illness spreading from England later in the year that caused the death within twentyfour hours of those infected (McGladdery 1990: 160). The description of this episode has led to conjectural identification of the pathogen at work as Vibrio cholerae - cholera (Creighton 1894: 235; Shrewsbury 1970: 150). Individually, such accounts offer meagre evidence for environmental or population historians to build upon, but cumulatively their record points to a kingdom wracked by successive waves of epidemic that culled first somewhere between $30 \%$ and (on current European estimates) $60 \%$ of the human population, and then kept the remaining population at the reduced level - or lower - for the remainder of the medieval period. This was the Scotland of Andrew of Wyntoun; most definitely not a land 'off wyne and wax, gamyn and gle'!

How beyond the obvious did such environmental factors change medieval Scotland? The answer is: at every level from social and economic, political and cultural, to psychological - but probably to regionally variable extents (Jillings 2003: chapter 2). The eastern Lowlands were buffered to some degree from the worst of the climatic deterioration and here the sharp plaguedriven contraction in population may have eased pressure on food supplies that the poorer growing conditions had brought, but population decline and limited availability of resources contributed to economic stagnation. In the north and west, the full impact of climate change and weather events moving in from the Atlantic stimulated profound change as it affected behaviour at all social levels (Oram 2010; Oram \& Adderley 2008; Oram \& Adderley 2010). The failure of long-established fishing-based economies in the Western Isles before the end of the 14th century, contraction of the grazing resources for the cattle-based society and economy of much of the Highlands (possibly already devastated by the murrain), and deterioration of soil conditions as increased rainfall leached nutrients and accelerated erosion stimulated major socio-political reorientation.

For deep-water fishing-dependent communities, such as had evolved in the Outer Hebrides by the 11th century, climate change brought 
potential disaster. The interplay of the Atlantic Meridional Overturning Circulation of oceanic water - transporting warmer water north and east across the Atlantic - with the North Atlantic Oscillation [hereafter NAO] in the atmospheric pressure systems (between the permanent Iceland low pressure and Azores high pressure cells), was a key factor in the establishment of the MCA and the LIA that followed, through their influence on westerly wind conditions and eastwards movement of atmospheric moisture. Positive NAO through much of the 10th to mid13th centuries brought a generally more benign weather regime to Atlantic Scotland, but from the 1250s the NAO weakened, resulting in a shift to greater variation, but principally to cooler and wetter summers and intensely cold and stormy winters. Palaeoenvironmental evidence from excavations in the Western Isles, particularly in Mound 3 at Bornais in South Uist, reveals that the commercialised exploitation of marine fish resources collapsed in the 14th century (Ingrem in Sharples (ed) 2005: 157-8, 176; Serjeantson 2013: 78-9). The collapse has been linked traditionally to political upheaval in the region, but is now seen as relating to changes in ocean temperatures affecting the migratory behaviour of pelagic species such as herring, upon which the fish-trade was based, and the impact of increased oceanic swell and storminess on both potential fishing-days at sea and losses of craft and men. The consequences for fishingdependent communities down Scotland's western seaboard of the historic changes in bottom-water temperatures identified in sea-lochs such as Loch Sunart have yet to be considered (Cage \& Austin 2010). Long term, there was no recovery of large-scale regional community involvement in deep-water fishing, it being a recurring theme of writers from the 16th century onwards that the Hebrideans' exploitation of the fisheries off their shores was under-developed at best but generally non-existent (Serjeantson 2013: 14-20).

For terrestrial exploitation regimes the consequences were as grave. In Scotland's upland areas the most significant aspect of climate change in the 14th century was a contraction of the annual growing season. A shortening by around a month meant that significant grass growth on summer pastures in upland districts, capable of sustaining grazing herds, began later in May and ended earlier in September. Nor could the pastures bear grazing across the whole of that shortened period and it is possible that the summer pasturing of cattle at upland shieling locations was reduced by up to $20 \%$ in some areas. Furthermore, the biomass produced was no longer capable of sustaining the numbers of animals that may have been summered on these pastures during the MCA. Coupled with this factor was the probable reduction in the altitudinal range of grazing, as colder conditions lowered the elevation at which crops could be grown or pastures exploited productively. Even with modern techniques, the height range of improved land in most of northwestern Scotland rarely exceeds $100 \mathrm{~m}$ OD. The pressure, however, was not limited only to the higher altitude summer grazing, for the reduced growing season also affected hay production in low-level meadows, diminishing supplies of winter fodder, while winter grazing generally became stressed as herds had to be pastured there for longer periods each year. A further factor to be considered is the direct effect of poor weather on the physical condition of livestock. Sustained periods of high winds and rain cause sheep and cattle to lose body-heat and use more calories, thus preventing them from accumulating the body-mass wanted for meat production or the fat reserves to aid them through the winter. Calorie consumption to maintain body-heat, moreover, reduced production of milk needed both for feeding calves and lambs and also for dairy products. For a livestock-dependent culture, the consequences of a sustained period of climatic deterioration were dire.

Some modifiers need to be introduced into the image of unmitigated crisis. There is a deepseated view that hay-making and storage of winter fodder for livestock was rare generally in pre-Improvement Era Scottish agriculture, a perception based largely on conditions in the Outer Hebrides where higher mean winter temperatures enabled stock to be grazed outside through the winter months in most years. Records of high levels of mortality in over-wintered stock in the later 17 th and 18th centuries are commonly cited, usually supported by graphic 
examples of anecdotal testimony. Great caution needs to be exercised in using these accounts, however, as many were produced in reports with strong pro-Improvement agendas, and even greater caution should be used when attempting to project the circumstances reported in such literature back into the Middle Ages. It is, for example, very difficult to correlate the image of low over-wintering survival and the poor springtime condition of the livestock with the evidence for large-scale movement of live cattle (as well as preserved carcasses) from island and upland to lowland districts already in existence by the mid-15th century (see for example Burnett 1883: 46, 49, 51, 85, 154, 219, 231, 330, 374, 420, 484, 529, 534, 621, 629, 639, 657, 663). Equally problematical is the view of traditional agricultural practices in many highland and island areas as lacking in development of hay-making and winter fodder provision for stock (Walker 1812). The abundance throughout the medieval Gàidhealtachd of dail placenames, a generic term applied to hay-producing water meadows where seasonal grazing for cattle could be provided, coupled with service obligations of winning and leading hay, provision of hay as feed for stock in upland districts and the keeping of fodder in hay-yards in surviving estate rentals from the late 15 th century onwards, suggests an altogether more favourable picture than is presented by the Improvement literature (Rogers 1880: vol i 172; vol ii 95-6, 168, 183-5, 261). This more positive view, however, also needs to be tempered with recognition that the regime reflected in the rentals was one where hay and winter fodder were largely reserved for the flocks and herds of the landlords, with the tenants supplying the commodity but having little of it to support their own livestock.

What were the likely consequences of a sustained episode of environmental stress? A $15-20 \%$ reduction in the growing season on the economically vital summer pastures translates to about a $25-30 \%$ reduction in the carrying-capacity of that land. Economic response models of the impacts of deterioration in conditions for arable and fodder production for pre-modern Iceland suggest that prolonged periods of moderately poor growing seasons are more damaging than smaller numbers of more extreme climatic downturns; and that different responses may ensue (Simpson et al 2002; Adderley et al 2008). In this instance, the responses to a deterioration in stock conditions may first have seen efforts to increase numbers to make up for shortfalls in volume of meat and milk being produced, but it would have been evident quickly that all this strategy was producing was more ill-nourished animals and possibly a higher mortality level amongst them. Alongside herd management for dairying purposes, it was possibly out of these circumstances that the strategy of calf-slaughter, so well represented in the archaeological record, was adopted or increased (McCormick 1998; Serjeantson 2013: $50,52,53-7)$. A second response may have been a reassessment of souming levels, the estimates of carrying-capacity of the grazing that were applied throughout medieval Scotland (Ross 2006). Stock numbers consequently fell, with the main impact at the lower end of the social spectrum, where tenants of landlords who operated a rentbased exploitation regime became less capable of meeting their obligations. The loss of visible wealth and social prestige, and the ability to sustain the complex support systems upon which an elite culture of conspicuous consumption and display was carried, which that declining income entailed, required radical behavioural change if it was to be addressed effectively (see Oram \& Adderley 2008; Oram \& Adderley 2010 for discussion).

Arable regimes, too, faced significant problems, not least in the lowering of altitudes at which cereal-production was viable. The clearest evidence emerges at the end of the period under review here, but incidences occur from as early as the 13th century. Across Scotland there is record from the mid-1200s to early 1400 s for a destructive interplay of medieval arable practice - which included stripping of turf from dune areas to add to cultivated ground to deepen and enrich the soil - and storm events, most clearly visible in the wind-erosion of cultivated ground or the inundation of fields beneath deep expanses of wind-blown sand. From Baleshare and the Udal in North Uist, the northern Orkney islands to Eldbotle in East Lothian or Forvie in Aberdeenshire to Ayr Links on the Clyde coast, the archaeological record reveals catastrophic 
episodes of dune deflation and sand-blow, leading to abandonment of hard-won agricultural land into which a huge investment in soil-quality improvement and enrichment had been made by past generations (Gilbertson et al 1999; Hindmarch 2006; Hindmarch \& Oram 2012; Kirk 1953; Morrison et al 2008; Oram 2014; Cooper (ed) 1883: no 43). The generally poor weather through the middle of the century, characterised by cold and extended winters and cool, wet summers, brought further crop failures in Scotland, but in the exposed northern and western islands, windiness may have been more damaging in the long term, with the worst effects being felt in the following century. Wind erosion increased in Orkney towards the end of the 1400s, probably exacerbated by a run of cold, dry winters and long, hot summers that reduced soil moisture levels. Wry comments in charters and leases in the 1480s and 1490s label abandoned landholdings in Westray, Papa Westray and Sanday that had suffered severe erosion as 'blawin to Birrowne' (Bergen) (Thomson 1987: 130), a reference to the impact of wind on their lighter, sandy soils. Rentals from the 1490s and 1500s confirm this picture, with extensive areas of those islands described as 'blawin' or 'waist', the south part of Papa Westray being described as mostly 'all our (over) blawin with wattir and sand' (Peterkin 1820: 84, 85, 87-90, 93-9). This rental evidence suggests that despite a probably sharp decline in population from the 1350s and the associated contraction of acreages under arable cultivation, the incidence of erosion loss of agricultural land increased rather than declined in the later Middle Ages.

Some indication of the cumulative impact of war, famine and disease can be seen in falling property values, as revealed in the land assessment of 1366. While it can be said that the fall is, in part, a measure of peasant success in securing reductions in levels of rent paid, much of this decline most probably relates more directly to a sharp drop in population levels and the consequent ending of around a century of upward pressure in rental values; fewer people were now pursuing tenancies, even on the most productive land, and agricultural activity in marginal upland areas experienced shrinkage and abandonment. The 1366 assessment reveals that falling values affected all parts of the country; values north of the Tay fell $44 \%$, those to its south by around $52 \%$. If they are representative of population pressure, these figures suggests that population fell nationwide, which runs against those traditional views of Scotland's experience of the Black Death, discussed earlier, that imply a differential in impact related to dispersed settlement characteristics in the Highlands and more nucleated settlement in lowland areas, but matches arguments advanced elsewhere for the experience of the country in 16th- and 17thcentury epidemics (Oram 2008). What a collapse in population may have done, as argued by Grant, is simply heighten pre-existing contrasts between different Highland and Lowland agricultural regimes (Grant 1984: 78). Longer term, this contrast became entrenched and sharpened the cultural distinctions between Gàidhealtachd and Anglophone districts.

In this discussion of climate, weather and pathogens, it is perhaps too easy to lose sight of the human population and to fall into the trap of environmental determinism as the explanation for all significant changes evident in the political, social, economic and cultural dimensions of Scotland's later medieval history. This paper has sought to bring to the fore the environmental processes that give context to the experience of Scotland's people across the period from the mid13 th to early 15 th centuries, an era characterised by profound socio-political upheaval in which many of what have long been regarded as the defining characteristics of Scottish cultural identity were forged. Those characteristics were not the product of passivity in the face of irresistible environmental phenomena, but the result of human agency, of choices made as to how to respond to changing circumstances. While the language of change and the conditions which drove the changes may verge on the apocalyptic, the underlying narrative is one of responsiveness and resilience rather than inertia and collapse. As archaeological and social anthropological discourse has begun to move in that direction (Redman \& Kinzig 2003; Kinzig et al 2006), however, despite now nearly two decades of environmental history research in Scotland, the 
role of human responses to large scale and longterm environmental transitions as motors for cultural reconfiguration still all too rarely features in historical analyses.

There can be no trivialising of the role of political circumstances after 1296 in the social destabilisation of 14th-century Scotland. But political upheaval alone did not create the social, economic and cultural stresses that emerged in the course of the 14th century. Those stresses arose from the ending of the viability of the agricultural economic regime that had evolved across the MCA, upon which the edifices of social, political and cultural power and authority in 12th- and 13th-century Scotland - the tools for the 'making' of the medieval Scottish kingdom had been built, further compounded by the drastic decline in population caused by plague mortality. It was those who lived through and responded to these phenomena who framed the identity of the new Scotland that emerged in the later 15th and 16th centuries. Assigning greater significance to the role of environmental crisis in triggering fundamental social and political reordering has become something of a bandwagon in current historiography, but in the case of 14th- and early 15th-century Scotland we seem to have a clearcut case of climate change and disease driving the processes of reconfiguration in the mechanisms that underpin the economies and cultures which our ancestors shaped in response.

\section{REFERENCES}

Adderley, W P \& Simpson, I A 2006 'Soils and Palaeo-climate based evidence for past irrigation requirements in Norse Greenland', Journal of Archaeological Science 33: 166679.

Adderley, W P, Simpson, I A, \& Vésteinsson, O 2008 'Local-scale adaptations: A modelled assessment of soil, landscape, microclimatic, and management factors in Norse home-field productivities', Geoarchaeology 23: 500-27.

Annals of Connacht at: http://www.ucc.ie/ celt/published/T100011/index.html. Accessed October 2014.
Annals of Innisfallen at: http://www.ucc.ie/ celt/published/T100004/index.html. Accessed October 2014.

Annals of Loch Cé at: http://www.ucc.ie/ celt/published/T100010A/index.html. Accessed October 2014.

Annals of Ulster otherwise Annala Senait, Annals of Senat (Author: [unknown]) at: http://www. ucc.ie/celt/published/T100001B/index.html. Accessed October 2014.

Baillie, M G L 1999 'Putting Abrupt Environmental Change Back into Human History', in Slack, $\mathrm{P}$ (ed), Environments and Historical Change: the Linacre Lectures. Oxford: Oxford University Press.

Baillie, M G L \& Brown, D M 2005 'Dendrochronology and the Reconstruction of Fine Resolution Environmental Change in the Holocene', in Mackay, A W (ed), Global Change in the Holocene, 75-91. London: Arnold Publishers.

Barrow, G W S 1988 Robert Bruce and the Community of the Realm of Scotland, 3rd edn. Edinburgh: Edinburgh University Press.

Benedictow, O 2004 The Black Death 1346-1353: A Complete History. Woodbridge: Boydell Press.

Briffa, K R 2000 'Annual climate variability in the Holocene: Interpreting the message of ancient trees', Quaternary Science Reviews 19: 87105.

Briffa, K R, Jones, P D, Schweingruber, F H \& Osborn, T J 1998 'Influences of Volcanic Eruptions on Northern Hemisphere Summer Temperatures over the Past 600 Years', Nature 393: 450-5.

Briffa, K R, Jones, PD, Vogel, R B, Schweingruber, F H, Baillie, M G L, Shiyatov, S G \& Voganov, E A 1999 'European Tree Rings and Climate Change in the Sixteenth Century', Climate Change 43: 151-68.

Briffa, K R, Osborn, $\mathrm{T}$ J, Schweingruber, F H, Harris, I C, Jones, P D Shiyatov, S G \& Vaganov, E A 2001 'Low-frequency temperature variations from a northern tree ring density network', Journal of Geophysical Research 106 D3: 2929-41.

Brown, M 2004 The Wars of Scotland 1214-1371. Edinburgh: Edinburgh University Press. 
Brown, N 2001 History and Climate Change. A Eurocentric Perpsective. London: Routledge.

Burnett, G (ed) 1880 The Exchequer Rolls of Scotland, vol 3, 1379-1406. Edinburgh: HMSO.

Burnett, G (ed) 1883 The Exchequer Rolls of Scotland, vol 6, 1455-1460. Edinburgh: HMSO.

Cage, A G \& Austin, W E N 2010 'Marine climate variability during the last millennium: the Loch Sunart record, Scotland, UK', Quaternary Science Reviews 29: 1633-47.

Campbell, B M S 2007 Three Centuries of English Crop Yields, 1211-1491 at: http://www.crop yields.ac.uk. Accessed October 2014.

Campbell, B M S 2008 'Nature as Historical Protagonist: The Tawney Memorial Lecture 2008', http://www.yada-yada.co.uk/podcasts/ Blackwell/video/Tawney 2008/index. Accessed March 2009.

Campbell, B M S 2009 'Four famines and a pestilence: harvest, price and wage variations in England, 13th to 19th centuries', in Liljewall, B, Flygare, I A, Lange, U, Ljunggren, L \& Söderberg, J (eds), Agrarhistoria på många sätt, 28 studier om människan och jorden. Festskrift till Janken Myrdal på hans 60-årsdag, 23-56. Stockholm: Royal Swedish Academy of Agriculture and Forestry.

Campbell, B M S 2010 'Physical shocks, biological hazards, and human impacts: the crisis of the fourteenth century revisited', in Cavaciocchi, S (ed), Economic and Biological Interactions in Pre-Industrial Europe from the 13th to the 18th Centuries, 13-32. Florence: Florence University Press.

Cantor, N F 1997 In the Wake of the Plague: The Black Death and the World it Made. London: Simon \& Schuster.

Cavaciocchi, S (ed) 2010 Economic and Biological interactions in Pre-Industrial Europe from the 13th to the 18th Centuries. Florence: University of Florence Press.

Clark, G 2008 English Prices and Wages 1209_ 1914 at: http://gpih.ucdavis.edu/Datafilelist. htm. Accessed October 2014.

Cohn Jr, S K 2002 The Black Death Transformed. Disease and Culture in Renaissance Europe. London: Arnold Publishers.
Cooper, W S (ed) 1883 Charters of the Royal Burgh of Ayr. Edinburgh: David Douglas (for the Ayr and Wigton Archaeological Association).

Creighton, C 1894 A History of Epidemics in Britain. Cambridge: Cambridge University Press.

Crowley, T J \& Lowery, T S 2000 'How Warm Was the Medieval Warm Period?', Ambio 29: $51-4$.

Dawson, A G, Hickey, K, Mayewski, P A \& Nesje, A 2007 'Ice Core and Historical Indicators of Complex North Atlantic Climate Changes in the Fourteenth Century', The Holocene 17.4: 427-34.

Dugmore, A J et al 2007 'Norse Greenland Settlement: Reflections on Climate Change, Trade, and the Contrasting Fates of Human Settlements in the North Atlantic Islands', Arctic Anthropology 44.1: 12-36.

Dugmore, A J et al 2009 'Norse Greenland Settlement and Limits to Adaptation', in Adger, W N, Lorenzoni, I \& O’Brien, K L (eds), Adapting to Climate Change. Thresholds, Values, Governance, 96-113. Cambridge: Cambridge University Press.

Duncan, A A M 1975 Scotland: the Making of the Kingdom. Edinburgh: Edinburgh University Press.

Duncan, A A M (ed) 1976 Formulary E Scottish Letters and Brieves, 1286-1424. Glasgow: Glasgow University Press.

Dyer, C 2002 Making a Living in the Middle Ages: the People of Britain 850-1520. London: Yale University Press.

Fagan, B 2000 The Little Ice Age. How Climate Made History 1300-1850. New York: Basic Books.

Fawcett, R 2011 The Architecture of the Scottish Medieval Church 1100-1560. New Haven and London: Yale University Press.

Gemmill, E \& Mayhew, N 1995 Changing Values in Medieval Scotland: A Study of Prices, Money, and Weights and Measures. Cambridge: Cambridge University Press.

Gilbertson, D D, Schwenninger, J-L, Kemp, R A \& Rhodes, E J 1999 'Sand-drift and Soil Formation along an exposed North Atlantic Coastline: 14,000 Years of Diverse Geomorphological, Climatic and Human 
Impacts', Journal of Archaeological Science 26(4): 439-69.

Grant, A 1984 Independence and Nationhood: Scotland 1306-1469. London: Edward Arnold.

Herlihy, D 1997 The Black Death and the Transformation of the West. London: Harvard University Press.

Hindmarch, E 2006 Renaissance Golf Club at Archerfield, Evaluation and Excavation Data Structure Report. Unpublished report by AOC Archaeology Group.

Hindmarch, E \& Oram, R D et al 2012 'Eldbotle: the archaeology and environmental history of a medieval rural settlement in East Lothian', Proc Soc Antiq Scot 142: 245-99.

Horrox, R (ed) 1994 The Black Death. Manchester: Manchester University Press.

Innes, C (ed) 1840 Liber Cartarum Sancte Crucis. Edinburgh: Banatyne Club.

Jillings, K 2003. Scotland's Black Death: The Foul Death of the English. Stroud: Tempus Publishing Ltd.

Jordan, W C 1996 The Great Famine: Northern Europe in the Early Fourteenth Century. Princeton: Princeton University Press.

Kershaw, I 1973 'The Great Famine and Agrarian Crisis in England 1315-22', Past and Present 59: 3-50.

Kinzig, A, Ryan, P, Etienne, M, Allison, H, Elmqvist, T \& Walker, B H 2006 'Resilience and Regime Shifts: Assessing Cascading Effects', Ecology and Society 11.1: 20. Online at: http://www.ecologyandsociety.org/vol11/ iss 1/art20/. Accessed December 2010.

Kirk, W 1953 'Prehistoric sites at the sands of Forvie, Aberdeenshire: a preliminary examination', Aberdeen University Review 35: 150-71.

Laing, D (ed) 1872 Androw of Wyntoun's Orygynale Cronykil of Scotland, vol 2. Edinburgh: Edmonston \& Douglas.

Laing, D (ed) 1879 Androw of Wyntoun's Orygynale Cronykil of Scotland, vol 3. Edinburgh: Edmonston \& Douglas.

Luard, H R (ed) 1880 Matthai Parisiensis Monachi Sancti Albani Chronica Majora, vol 5. London: Rolls Series.
Lyons, M 1988 'Weather, Famine, Pestilence and Plague in Ireland', in Crawford, E M (ed), Famine: the Irish Experience 900-1900. Subsistence Crises and Famines in Ireland. Edinburgh: John Donald.

McCormick, F 1998 'Calf slaughter as a response to marginality', in Mills, C M and Coles, G (eds), Life on the Edge - Human Settlement in Marginal Areas, 49-51. Oxford: Oxbow Books.

McGladdery, C A 1990 James II. Edinburgh: John Donald.

McGovern, T H, Bigelow, G, Amorosi, T \& Russell, D 1988 'Northern Islands, Human Error, and Environmental Degradation: A View of Social and Ecological Change in the Medieval North Atlantic', Human Ecology 16.3: 225-70.

McGovern, T H, Vésteinsson, O, Fridriksson, A, Church, M, Lawson, I, Simpson, I A, Einarsson, A, Dugmore, A, Cook, G, Perdikaris, S, Edwards, K J, Thomson, A M, Adderley, W P, Newton A, Lucas, G, Edvardsson, R, Aldred, O \& Dunbar, E 2007 'Landscapes of Settlement in Northern Iceland: Historical Ecology of Human Impact and Climate Fluctuation on the Millennial Scale', American Anthropologist 109: 27-51.

McNamee, C 1997 The Wars of the Bruces. Scotland, England and Ireland 1306-1328. East Linton: Tuckwell Press.

Mann, M E 2002 'Little Ice Age', in MacCracken, M C \& Perry, J S (eds), Encyclopedia of Global Environmental Change, vol 1: 1-6. Chichester: John Wiley \& Sons.

Mayewski, P A, Meeker, L D, Whitlow, S, Twickler, M S, Morrison, M C, Bloomfield, P, Bond, G C, Alley, R B, Gow, A J, Meese, D A, Grootes, P M, Ram, M, Taylor, K C \& Wumkes, W 1994 'Changes in atmospheric circulation and ocean ice cover over the North Atlantic during the last 41,000 years', Science 263(5154): 1747-51.

Mayewski, P A, Rohling, E E, Stager, J C, Karlén, W, Maascha, K A, Meeker, L D, Meyerson, E A, Gasse, F, van Kreveld, S, Holmgren, K, Lee-Thorp, J, Rosqvist, G, Rack, F, Staubwasser, M, Schneider, R R \& Steig, E G 2004 'Holocene Climate Variability', Quaternary Research 62: 243-55. 
Mayhew, N 1990 'Alexander III - A Silver Age? An Essay in Scottish Medieval Economic History', in Reid, N (ed), Scotland in the Reign of Alexander III 1249-1286, 53-73. Edinburgh: John Donald.

Morrison, J, Oram, R \& Oliver, F 2008 'Ancient Eldbottle Unearthed: archaeological and historical evidence for a long-lost early medieval East Lothian village', Transactions of the East Lothian Antiquarian and Field Naturalists' Society 27: 21-45.

Munro, J 2008 Revision of Phelps Brown and Hopkins' 'basket of consumables' commodity price series and craftsmen's wage series at: http://www.economics.utoronto.ca/munro5/ EngBasketPrices.xls. Accessed 15 October 2014.

Naphy, W \& Spicer, A 2000 The Black Death. A History of Plagues 1345-1730. Stroud: Tempus Publishing Ltd.

Newfield, T P 2009 'A cattle panzootic in early fourteenth-century Europe', Agricultural History Review 57.2: 155-99.

Oppenheimer, C 2003 'Ice Core and Palaeoclimatic Evidence for the Timing and Nature of the Great Mid-13th Century Volcanic Eruption', International Journal of Climatology 23: 41726.

Oram, R D 2008 “"It cannot be decernit quha are clean and quha are foulle." Responses to epidemic disease in sixteenth- and seventeenth-century Scotland', Renaissance and Reformation 30: 13-39.

Oram, R D 2010 'Innse Gall: Culture and Environment on a Norse Frontier in the Scottish Western Isles', in Imsen, S (ed), The Norgesveldet in the Middle Ages, 125-48. Trondheim: Tapir Press.

Oram, R D 2011 Domination and Lordship. Scotland 1070-1230. Edinburgh: Edinburgh University Press.

Oram, R D 2014 "From "Golden Age" to Depression: Land Use and Environmental Change in the Medieval Earldom of Orkney', in Gulløv, H C (ed), Northern Worlds: Landscapes, Interactions and Dynamics. Copenhagen: National Museum of Denmark.

Oram, R D \& Adderley, P 2008 'Lordship and environmental change in central Highland
Scotland $c 1300$ to $c 1450$ ', Journal of the North Atlantic 1: 74-84.

Oram, R D \& Adderley, P 2010 'Lordship, land and environmental change in West Highland and Hebridean Scotland c1300-c1450', in Cavaciocchi, S (ed), Economic and Biological interactions in Pre-Industrial Europe from the 13th to the 18th Centuries, 257-68. Florence: University of Florence Press.

Ormrod, W M \& Lindley, P G 2003 The Black Death in England. Donington: Shaun Tyas.

Peterkin, A 1820 Rentals of the Ancient Earldom and Bishoprick of Orkney: With Some Other Explanatory and Relative Documents. Edinburgh: John Moir.

Pfister, C, Schwarz-Zanetti, G \& Wegman, M 1996 'Winter Severity in Europe: the Fourteenth Century', Climatic Change 34: 91-108.

Phelps Brown, H \& Hopkins, S 1981 A Perspective of Wages and Prices. London: Methuen.

Postan, M M 1972 The Medieval Economy and Society. London: Weidenfeld \& Nicolson.

Prestwich, M 1988 Edward I. London: Methuen.

Redman, C L \& Kinzig, A P 2003 'Resilience of Past Landscapes: Resilience Theory, Society, and the Longue Durée', Conservation Ecology 7.1: 14. Online at: http://www.consecol.org/ vol17/iss1/art14. Accessed December 2010.

Rogers, C (ed) 1880 Rental Book of the Cistercian Abbey of Cupar-Angus, 2 vols. London: Grampian Club.

Ross, A 2006 'Scottish Environmental History and the (Mis)use of Soums', Agricultural History Review 54: 213-38.

Self, S, Zhao, J-X, Holasek, R E, Torres, R C \& King, A J 1998 'The Atmospheric Impact of the 1991 Mt Pinatubo Eruption', in Newhall, C G, Punongbayan, R S, Fire and Mud, Eruptions and Lahars of Mount Pinatubo, Philippines. Washington: Smithsonian Institution - Global Volcanism Program: online at: http://pubs. usgs.gov/pinatubo/self/index.html. Accessed October 2014

Serjeantson, D 2013 Farming and Fishing in the Outer Hebrides $A D 600$ to 1700. Southampton: The Highfield Press.

Sharples, N M (ed) 2005 A Norse Farmstead in the Outer Hebrides: Excavations at Mound 3, Bornais, South Uist. Oxford: Oxbow Books. 
Shrewsbury, J F D 1970 A History of the Bubonic Plague in the British Isles. Cambridge: Cambridge University Press.

Simpson, I A, Adderley, W P, Guðmundsson, G, Hallsdóttir, M, Sigurgeirsson, M Á \& Snæsdóttir, M 2002 'Land management for surplus grain production in early Iceland', Human Ecology 30: 423-43.

Skene, W F (ed), 1872 John of Fordun's Chronicle of the Scottish Nation, vol 2. Edinburgh: William Paterson.

Slavin, P 2010 'The Fifth Rider of the Apocalypse: the Great Cattle Plague in England and Wales and its Economic Consequences', in Cavaciocchi, S (ed), Economic and Biological Interactions in Pre-Industrial Europe from the 13th to the 18th Centuries, 165-79. Florence: Florence University Press.

Stevenson, J (ed) 1839 Chronicon de Lanercost. Edinburgh: Bannatyne Club.

Strothers, R B 2000 'Climatic and Demographic Consequences of the Massive Volcanic Eruption of 1258', Climate Change 45: 36174.

Stuart, J \& Burnett, G (eds) 1878 The Exchequer Rolls of Scotland, vol 1, 1264-1359. Edinburgh: HMSO.

Thomson, W P 1987 History of Orkney. Edinburgh: The Mercat Press.

Thorold Rogers, J E 1866-1902 A History of Agriculture and Prices in England, 7 vols. Oxford: Oxford University Press.
Tuchman, B W 1979 A Distant Mirror. The Calamitous Fourteenth Century. London: Ballantine Books/Random House.

Vinther, B M, Johnsen, S J, Andersen, K K, Clausen, H B \& Hansen, A W 2003 'NAO signal recorded in the stable isotopes of the Greenland icecores', Geophysical Research Letters 30: 1387.

Walker, J 1812 An Economical History of the Hebrides and Highlands of Scotland. Edinburgh: Longman.

Watt, D E R et al (eds) 1987 Scotichronicon by Walter Bower, vol 8. Aberdeen: Aberdeen University Press.

Watt, D E R et al (eds) 1990 Scotichronicon by Walter Bower, vol 5. Aberdeen: Aberdeen University Press.

Watt, D E R et al (eds) 1991 Scotichronicon by Walter Bower, vol 6. Aberdeen: Aberdeen University Press.

Watt, D E R et al (eds) 1996 Scotichronicon by Walter Bower, vol 7. Aberdeen: Aberdeen University Press.

Webster, B (ed) 1984 Regesta Regum Scottorum, vol 6, The Acts of David II. Edinburgh: Edinburgh University Press.

Whittington, G 1985 'The little ice age and Scotland's weather', Scottish Geographical Journal 101.3: 174-8.

Ziegler, P 2003 The Black Death. Stroud: Sutton Publishing. 
Table 1

Weather events, famine and epidemics in Scotland, northern England and Ireland from chronicle sources 1251-1447

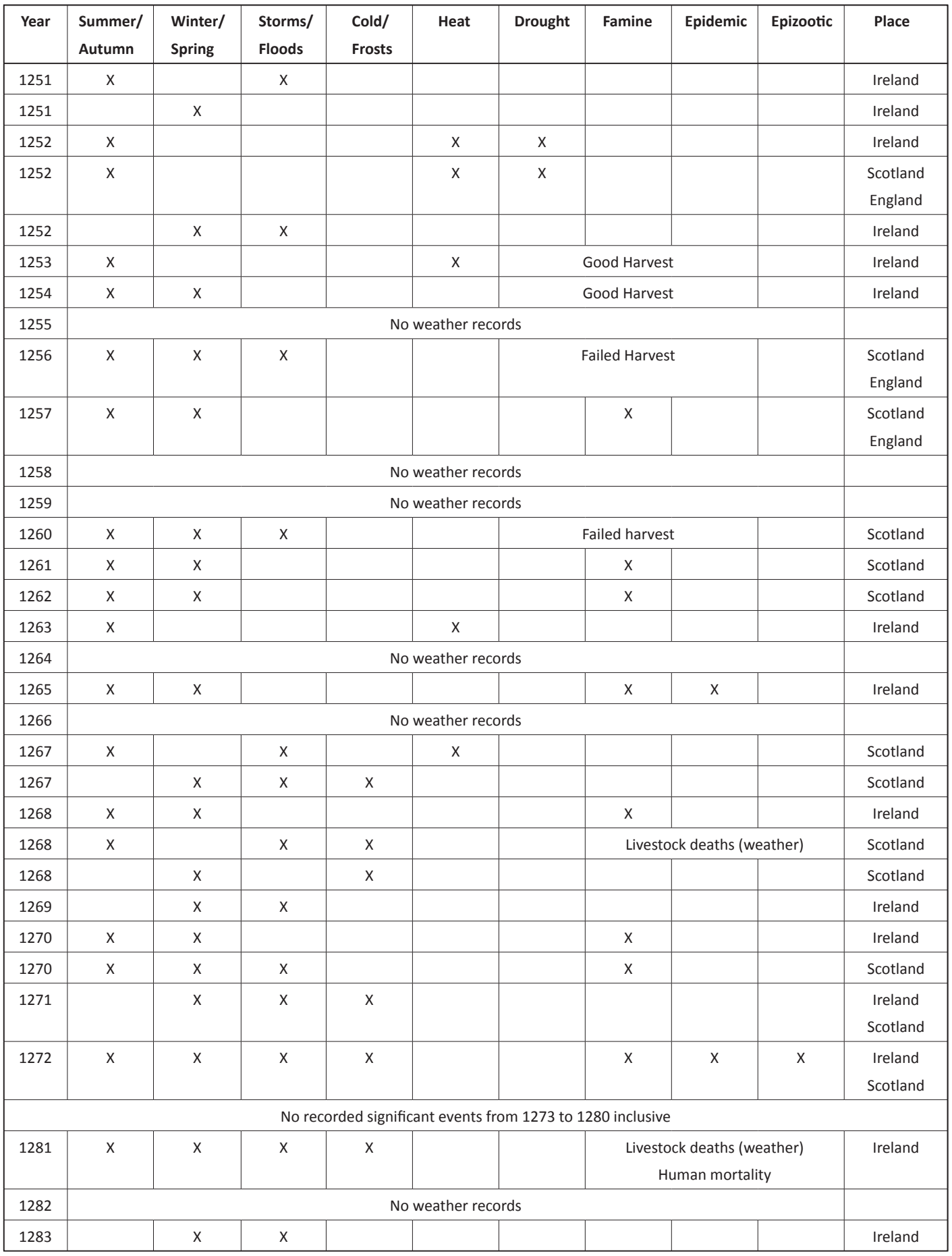


'THE WORST DISASTER SUFFERED BY THE PEOPLE OF SCOTLAND IN RECORDED HISTORY'

\begin{tabular}{|c|c|c|c|c|c|c|c|c|c|c|}
\hline Year & $\begin{array}{l}\text { Summer/ } \\
\text { Autumn }\end{array}$ & $\begin{array}{l}\text { Winter/ } \\
\text { Spring }\end{array}$ & $\begin{array}{l}\text { Storms/ } \\
\text { Floods }\end{array}$ & $\begin{array}{l}\text { Cold/ } \\
\text { Frosts }\end{array}$ & Heat & Drought & Famine & Epidemic & Epizootic & Place \\
\hline 1284 & $\mathrm{x}$ & & $\mathrm{x}$ & & & & & & & Ireland \\
\hline 1285 & & $\mathrm{x}$ & $\mathrm{x}$ & & & & & & & Ireland \\
\hline \multicolumn{11}{|c|}{ No recorded significant events from Summer 1286 until winter 1290/1 } \\
\hline 1291 & $\mathrm{x}$ & & $\mathrm{x}$ & & & & & & & England \\
\hline 1292 & $\mathrm{x}$ & $\mathrm{x}$ & $\mathrm{x}$ & & & \multicolumn{4}{|c|}{ Coastal inundations/floods } & England \\
\hline 1293 & $\mathrm{x}$ & $\mathrm{x}$ & $\mathrm{x}$ & $x$ & & & $\mathrm{x}$ & & & $\begin{array}{l}\text { Scotland } \\
\text { England }\end{array}$ \\
\hline 1294 & $\mathrm{x}$ & & $\mathrm{x}$ & & & & & & & Scotland \\
\hline 1295 & \multicolumn{9}{|c|}{ No weather records } & \\
\hline 1296 & & $\mathrm{x}$ & $\mathrm{x}$ & $\mathrm{x}$ & & & & & $\mathrm{x}$ & $\begin{array}{l}\text { Ireland } \\
\text { Scotland } \\
\text { England }\end{array}$ \\
\hline 1297 & $\mathrm{x}$ & & & & & & $\mathrm{x}$ & & & $\begin{array}{l}\text { Scotland } \\
\text { England }\end{array}$ \\
\hline \multicolumn{11}{|c|}{ No recorded significant events from Autumn 1297 until Summer 1305} \\
\hline 1305 & $\mathrm{x}$ & & & & & & $\mathrm{x}$ & & & Ireland \\
\hline \multicolumn{11}{|c|}{ No recorded significant events from Autumn 1305 until winter 1308/9 } \\
\hline 1308 & & $\mathrm{x}$ & $x$ & & & & $\begin{array}{l}\text { Livest } \\
\text { Huma }\end{array}$ & $\begin{array}{l}\mathrm{k} \text { deaths ( } \mathrm{W} \\
\text { mortality ( }\end{array}$ & $\begin{array}{l}\text { ather) } \\
\text { ather) }\end{array}$ & Ireland \\
\hline 1309 & \multicolumn{9}{|c|}{ No weather records } & \\
\hline 1310 & $x$ & & $\mathrm{x}$ & & & \multicolumn{3}{|c|}{$\begin{array}{c}\text { Good harvest (Ireland) } \\
\text { War-related food shortages } \\
\text { (Scotland) }\end{array}$} & & $\begin{array}{l}\text { Ireland } \\
\text { Scotland }\end{array}$ \\
\hline \multicolumn{11}{|c|}{ No recorded significant events from Autumn 1310 until Spring 1313/4 } \\
\hline 1314 & $\mathrm{x}$ & $\mathrm{x}$ & & & & & $x$ & & & Ireland \\
\hline 1315 & $\mathrm{x}$ & $\mathrm{x}$ & $\mathrm{x}$ & $\mathrm{x}$ & & & $\mathrm{x}$ & $\mathrm{x}$ & & $\begin{array}{l}\text { Ireland } \\
\text { Scotland }\end{array}$ \\
\hline 1316 & $x$ & $\mathrm{x}$ & $\mathrm{x}$ & $\mathrm{x}$ & & & $x$ & $x$ & & $\begin{array}{l}\text { Ireland } \\
\text { Scotland } \\
\text { England }\end{array}$ \\
\hline 1317 & $x$ & $x$ & & & & & $x$ & & & Ireland \\
\hline 1318 & $x$ & $x$ & $x$ & $x$ & & & & & & Ireland \\
\hline 1319 & $x$ & $\mathrm{x}$ & & & & & & & $x$ & $\begin{array}{l}\text { Scotland } \\
\text { England }\end{array}$ \\
\hline 1320 & \multicolumn{9}{|c|}{ No weather records } & \\
\hline 1321 & & $\mathrm{x}$ & $\mathrm{x}$ & $x$ & & \multicolumn{4}{|c|}{ Livestock deaths (weather) } & Scotland \\
\hline \multicolumn{11}{|c|}{ No recorded significant events for $1322-1324$} \\
\hline 1325 & $x$ & $x$ & $x$ & & & & & & $x$ & Ireland \\
\hline 1326 & \multicolumn{9}{|c|}{ No weather records } & \\
\hline 1327 & $\mathrm{x}$ & & & & & & ood harve & & & Scotland \\
\hline 1327 & $x$ & & & & & & & $x$ & & Ireland \\
\hline 1328 & $\mathrm{x}$ & $\mathrm{x}$ & $\mathrm{x}$ & & & $\mathrm{x}$ & $\mathrm{x}$ & & & Ireland \\
\hline
\end{tabular}




\begin{tabular}{|c|c|c|c|c|c|c|c|c|c|c|}
\hline Year & $\begin{array}{l}\text { Summer/ } \\
\text { Autumn }\end{array}$ & $\begin{array}{l}\text { Winter/ } \\
\text { Spring }\end{array}$ & $\begin{array}{l}\text { Storms/ } \\
\text { Floods }\end{array}$ & $\begin{array}{l}\text { Cold/ } \\
\text { Frosts }\end{array}$ & Heat & Drought & Famine & Epidemic & Epizootic & Place \\
\hline 1329 & $x$ & $x$ & $x$ & & & \multicolumn{3}{|c|}{ Poor/late harvest } & & Ireland \\
\hline \multicolumn{11}{|c|}{ No recorded weather events from Winter $1329 / 30$ to Winter $1335 / 6$} \\
\hline 1335 & & $x$ & $x$ & $x$ & & & & & & Ireland \\
\hline 1336 & $\mathrm{x}$ & $\mathrm{x}$ & & & & & & & $\begin{array}{l}X \text { (fowl } \\
\text { pest) }\end{array}$ & Scotland \\
\hline 1337 & $x$ & $x$ & & & & & $x$ & & & Scotland \\
\hline 1338 & & $\mathrm{x}$ & $\mathrm{x}$ & $\mathrm{x}$ & & & $\mathrm{x}$ & & $\begin{array}{c}\mathrm{X} \\
\text { (weather) }\end{array}$ & Ireland \\
\hline \multicolumn{11}{|c|}{ No recorded events from Spring 1339 until Summer 1348} \\
\hline 1348 & $\mathrm{x}$ & $\mathrm{x}$ & & & & & & $\begin{array}{c}\mathrm{X} \\
\text { Black } \\
\text { Death } \\
\text { Enters } \\
\text { England }\end{array}$ & & $\begin{array}{l}\text { England } \\
\text { Ireland }\end{array}$ \\
\hline 1349 & $\mathrm{x}$ & $\mathrm{x}$ & & & & & & $\mathrm{x}$ & & $\begin{array}{l}\text { England } \\
\text { Ireland } \\
\text { Scotland }\end{array}$ \\
\hline 1350 & $\mathrm{x}$ & $x$ & & & & & & $\mathrm{x}$ & & $\begin{array}{l}\text { England } \\
\text { Ireland } \\
\text { Scotland }\end{array}$ \\
\hline 1351 & $x$ & $x$ & & & & & & $x$ & & $\begin{array}{l}\text { England } \\
\text { Ireland } \\
\text { Scotland }\end{array}$ \\
\hline \multicolumn{11}{|c|}{ No recorded events for 1352 to Winter $1355 / 6$} \\
\hline 1355 & & $x$ & $x$ & & & & & & & Scotland \\
\hline 1356 & & & No significa & weather & nts from & ing $1356 \mathrm{t}$ & pring 1358 & & & \\
\hline 1358 & $\mathrm{x}$ & & $\mathrm{x}$ & $\mathrm{x}$ & & & & & & $\begin{array}{l}\text { Ireland } \\
\text { Scotland }\end{array}$ \\
\hline 1359 & \multicolumn{10}{|c|}{ No significant weather events } \\
\hline 1360 & $x$ & $x$ & $x$ & & & & & & & Ireland \\
\hline 1361 & $x$ & $x$ & & & & & & $x$ & & $\begin{array}{l}\text { England } \\
\text { Ireland }\end{array}$ \\
\hline 1362 & $x$ & $x$ & & & & & & $x$ & & $\begin{array}{l}\text { England } \\
\text { Scotland }\end{array}$ \\
\hline 1363 & $\mathrm{x}$ & $\mathrm{x}$ & & & & & & $x$ & & $\begin{array}{l}\text { England } \\
\text { Scotland }\end{array}$ \\
\hline \multicolumn{11}{|c|}{ No recorded significant events for 1364 to 1369} \\
\hline 1369 & $x$ & $\mathrm{x}$ & $x$ & & & & $x$ & $x$ & $x$ & $\begin{array}{l}\text { England } \\
\text { Ireland }\end{array}$ \\
\hline 1370 & $x$ & $\mathrm{x}$ & & & & & & $x$ & & $\begin{array}{l}\text { England } \\
\text { Ireland }\end{array}$ \\
\hline 1371 & $x$ & $x$ & $x$ & & & & & $x$ & $x$ & $\begin{array}{l}\text { England } \\
\text { Ireland }\end{array}$ \\
\hline
\end{tabular}


'THE WORST DISASTER SUFFERED BY THE PEOPLE OF SCOTLAND IN RECORDED HISTORY'

\begin{tabular}{|c|c|c|c|c|c|c|c|c|c|c|}
\hline Year & $\begin{array}{l}\text { Summer/ } \\
\text { Autumn }\end{array}$ & $\begin{array}{l}\text { Winter/ } \\
\text { Spring }\end{array}$ & $\begin{array}{l}\text { Storms/ } \\
\text { Floods }\end{array}$ & $\begin{array}{l}\text { Cold/ } \\
\text { Frosts }\end{array}$ & Heat & Drought & Famine & Epidemic & Epizootic & Place \\
\hline 1372 & & $x$ & $x$ & & & & & & & Scotland \\
\hline 1373 & $x$ & $x$ & $x$ & & & & & & & Ireland \\
\hline 1374 & $x$ & $x$ & & & & & & $x$ & & England \\
\hline 1375 & $x$ & $x$ & & & & & & $x$ & & England \\
\hline 1376 & $x$ & $x$ & & & $x$ & & & $x$ & & England \\
\hline 1378 & $x$ & $x$ & & & & & & $x$ & & England \\
\hline 1379 & $x$ & $x$ & & & & & & $x$ & & England \\
\hline 1380 & $x$ & $x$ & & & & & & $x$ & & $\begin{array}{l}\text { England } \\
\text { Scotland }\end{array}$ \\
\hline \multicolumn{11}{|c|}{ No significant recorded events from Winter 1380/1 until Summer 1390} \\
\hline 1390 & $x$ & $x$ & & & & & & $x$ & & England \\
\hline 1391 & $x$ & $x$ & & & & & & $x$ & & England \\
\hline 1392 & $x$ & $x$ & & & & & & $x$ & & $\begin{array}{l}\text { England } \\
\text { Scotland }\end{array}$ \\
\hline 1393 & $x$ & $x$ & & & & & & $x$ & & England \\
\hline \multicolumn{11}{|c|}{ No significant recorded events from Winter 1393/4 to Spring 1397} \\
\hline 1397 & $\mathrm{x}$ & & $\mathrm{x}$ & $\mathrm{x}$ & & & $\mathrm{x}$ & & & Ireland \\
\hline \multicolumn{11}{|c|}{ No significant recorded events from Autumn 1397 to Winter 1400/1401 } \\
\hline 1401 & $x$ & $\mathrm{x}$ & & & & & & $x$ & & Scotland \\
\hline \multicolumn{11}{|c|}{ No significant recorded events Spring 1402 to Autumn 1405} \\
\hline 1405 & & $\mathrm{X}$ & $\mathrm{x}$ & & & & & & & Ireland \\
\hline 1406 & \multicolumn{9}{|c|}{ No significant weather events } & \\
\hline 1407 & $x$ & $\mathrm{x}$ & $\mathrm{x}$ & & & & & & $\begin{array}{c}\mathrm{x} \\
\text { (weather) }\end{array}$ & Ireland \\
\hline 1408 & \multicolumn{9}{|c|}{ No significant weather events } & \\
\hline 1409 & & $\mathrm{x}$ & $\mathrm{x}$ & & & & & & & Scotland \\
\hline \multicolumn{11}{|c|}{ No significant recorded events from Spring 1410 to 1413} \\
\hline 1413 & $x$ & & $\mathrm{x}$ & & & & & & & Ireland \\
\hline \multicolumn{11}{|c|}{ No significant recorded events from Winter 1413/4 until Spring 1419} \\
\hline 1419 & $x$ & & & & $x$ & $x$ & & jood harvest & & $\begin{array}{l}\text { Ireland } \\
\text { Scotland }\end{array}$ \\
\hline 1420 & $x$ & $x$ & & & & Harve & ailure & $x$ & & Scotland \\
\hline 1421 & $x$ & & $\mathrm{x}$ & & & & & & & Scotland \\
\hline \multicolumn{11}{|c|}{ No significant recorded events from Winter $1421 / 2$ until Winter $1424 / 5$} \\
\hline 1425 & $\mathrm{x}$ & $\mathrm{x}$ & $\mathrm{x}$ & $\mathrm{x}$ & & Poor & vest & $x$ & & $\begin{array}{l}\text { Ireland } \\
\text { Scotland }\end{array}$ \\
\hline \multicolumn{11}{|c|}{ No significant recorded events from Spring 1426 until Autumn 1431} \\
\hline 1431 & & $x$ & $x$ & $x$ & & & & $x$ & $\begin{array}{c}\mathrm{X} \\
\text { (weather) }\end{array}$ & $\begin{array}{c}\text { Scotland } \\
\text { Ireland }\end{array}$ \\
\hline 1432 & $x$ & $x$ & & & & & & $x$ & & Scotland \\
\hline 1433 & $x$ & & & & & & $x$ & & & Ireland \\
\hline
\end{tabular}




\section{4 | SOCIETY OF ANTIQUARIES OF SCOTLAND, 2014}

\begin{tabular}{|c|c|c|c|c|c|c|c|c|c|c|}
\hline Year & $\begin{array}{l}\text { Summer/ } \\
\text { Autumn }\end{array}$ & $\begin{array}{l}\text { Winter/ } \\
\text { Spring }\end{array}$ & $\begin{array}{l}\text { Storms/ } \\
\text { Floods }\end{array}$ & $\begin{array}{l}\text { Cold/ } \\
\text { Frosts }\end{array}$ & Heat & Drought & Famine & Epidemic & Epizootic & Place \\
\hline 1434 & & $x$ & $x$ & $x$ & & & & & & $\begin{array}{l}\text { Scotland } \\
\text { Ireland }\end{array}$ \\
\hline 1435 & $x$ & $x$ & & $x$ & & & $x$ & & & $\begin{array}{l}\text { Scotland } \\
\text { Ireland }\end{array}$ \\
\hline \multicolumn{11}{|c|}{ No significant recorded events for $1436-1437$} \\
\hline 1438 & $x$ & & & & & & & $x$ & & Ireland \\
\hline 1439 & $x$ & $x$ & & & & & $x$ & $x$ & & $\begin{array}{l}\text { Scotland } \\
\text { Ireland }\end{array}$ \\
\hline 1440 & $x$ & $x$ & & & & & & $x$ & & Ireland \\
\hline \multicolumn{11}{|c|}{ No significant recorded events $1441-1446$} \\
\hline 1447 & $x$ & $x$ & $x$ & & & & & $x$ & & $\begin{array}{l}\text { Scotland } \\
\text { Ireland }\end{array}$ \\
\hline
\end{tabular}

Note: the calendar years run from 25 March, hence the Summer/Autumn and Winter/Spring arrangement. 